\title{
Rozważania o efektywności i konkurencyjności płatnika trzeciej strony na przykładzie Narodowego Funduszu Zdrowia
}

\author{
Piotr Bromber*
}

W niniejszym artykule zaprezentowano sposób ujęcia efektywności platnika trzeciej strony. Jednocześnie dokonano charakterystyki Narodowego Funduszu Zdrowia oraz zaprezentowano przyktadowe obszary konkurencji w relacji ptatnik-świadczeniodawca i ptatnik-świadczeniobiorca. Autor $z$ duża rezerwa pochodzi do wprowadzenia konkurencji $w$ obszarze ceny za świadczenia opieki zdrowotnej. Stąd też nie udziela $w$ tym zakresie jednoznacznych odpowiedzi, a co najwyżej sygnalizuje pewne watpliwości i zadaje pytania. Natomiast jest przekonany co do istnienia przestanek dających możliwość zwiększenia potencjału Narodowego Funduszu Zdrowia.

Dlatego za konieczne uznaje podjęcie dziatań majacych na celu identyfikacje dysfunkcji $i$ zaprojektowanie stosowanych zmian zarówno na poziomie instytucji, jak $i$ w otoczeniu. $W$ tym zakresie proponuje dokonać przeglądu rozwiązań będących propozycja zmian $w$ zakresie funkcjonowania ptatnika.

Słowa kluczowe: Narodowy Fundusz Zdrowia, płatnik trzeciej strony, konkurencyjność, efektywność

Nadesłany: 07.11.2012 | Zaakceptowany do druku: 15.12.2012

\section{Considerations concerning the efficiency and competitiveness of the third party payer on the basis of the National Healthcare Fund}

The paper presents a form of analyzing the efficiency of the third party payer. The analysis includes the characteristics of the National Healthcare Fund and presentation of examples of the areas of competition in the following relations: payer - he healthcare provider and payer - beneficiary (patient).

The idea of introducing price competition in the area of healthcare provision is treated rather cautiously. Hence no unequivocal answers are given. Certain doubts are highlighted and several questions are asked. It is specifically suggested that there exist prerequisites for increasing the potential of the National Healthcare Fund.

Thus it is vital to undertake actions aimed at identification of dysfunctions and formulation of relevant changes both at the level of the institution as well as in its environment. Potential solutions concerning changes in the functioning of the payer have to be reviewed.

Keywords: the National Healthcare Fund, third party payer, competitiveness, efficiency

Submitted: 07.11.2012 | Accepted: 15.12.2012

JEL: I10; I13

Piotr Bromber - Uniwersytet Zielonogórski

Adres do korespondencji: Katedra Makroekonomii i Finansów, Wydział Ekonomii i Zarządzania, Uniwersytet Zielonogórski, ul. Podgórna 50, 65-246 Zielona Góra, e-mail: brom2@tlen.pl. 


\section{Wprowadzenie}

Zdaniem językoznawców przymiotnik „efektywny” należy obecnie do jednych z najmodniejszych przymiotników używanych w biznesie (Biznes nie zna..., 2011)

Jest jednym $\mathrm{z}$ najczéściej pojawiajacych się terminów w naukach ekonomicznych, wykorzystywanym do opisu procesów gospodarowania (Różański, 2007, s. 426; Matwiejczuk, 2000, s. 27), przy czym bywa też pojęciem nadużywanym (Juzwiszyn, Rybicki, Smoluk, 2005, s. 192). Nic więc dziwnego, że efektywność jest też przedmiotem licznych dyskusji, publikacji poświęconych funkcjonowaniu ochrony zdrowia, w tym oceny płatnika ${ }^{1}$, tym bardziej obecnie, przy rosnacej dysproporcji między popytem na świadczenia opieki zdrowotnej a możliwościami ich finansowania.

W przekonaniu autora niejednokrotnie występuje tylko hasłowo jako postulat lub pożądany stan oczekiwanego zadowolenia i do artykulacji krytyki, np. krytyki Narodowego Funduszu Zdrowia (dalej: Funduszu lub NFZ).

Co to znaczy efektywny płatnik? Taki, który działa zgodnie $z$ prawem, realizuje przypisane zadania/cele przy relatywnie niskich kosztach?

W kontekście poniższych rozważań autor proponuje wyodrębnić trzy obszary badawcze:

1) Pojęcie efektywności (kryterium ekonomiczne, kryterium medyczne, kryterium społeczne, kryterium instytucjonalne);

2) Narodowy Fundusz Zdrowia (charakterystyka, percepcja działania, zmiany instytucjonalne i systemowe);

3) konkurencyjność.

\section{Efektywność w teorii}

W literaturze przedmiotu można spotkać różne ujęcia i zastosowania pojęcia efektywności. Inaczej jest ono definiowane w psychologii, inaczej w socjologii, prakseologii, naukach prawniczych czy ekonomii (Pudełkiewicz, 2004).

M. Holstein-Beck zwraca uwagę na wieloaspektowość podejścia do efektywności (Dubas, 2011, s. 103). Uwzględnienie różnych płaszczyzn efektywności postuluje E. Skrzypek. Wymienia efektywność organizacyjną, operacyjną, rynkową i finansową (Skrzypek 2000, s. 192).
W ramach niniejszego artykułu zaprezentowano cztery aspekty efektywności, przyjmując za punkt wyjścia następujące kryteria:

a) ekonomiczne,

b) społeczne (użyteczności),

c) medyczne,

d) instytucjonalne (organizacyjne).

$\mathrm{Na}$ wstępie niniejszych rozważań przyjęto, że pojęcie efektywności nie jest tożsame $\mathrm{z}$ pojęciem skuteczności ${ }^{2}$.

Ponadto uwzględniono, że efektywność należy odnosić zarówno do funkcjonowania poszczególnych podmiotów tworzacych system ochrony zdrowia, jak i systemu jako całości (Nojszewska, 2011, s. 14).

W ekonomii efektywność najczęściej jest ujmowana jako rezultat działań opisany za pomocą relacji efektów do nakładów (Meredyk, 2007, s. 257; Nowak, 1998, s. 11). Interesujący i nieco odmienny punkt widzenia zaproponował W. Misiagg. Rozpatrując efektywność finansów publicznych, zaproponował rozumienie efektywności jako osiągnięcie akceptowalnej relacji między wielkością wykorzystanych środków publicznych i efektami ich wykorzystania. Przy tym, jak sam podkreśla, świadomie unika budowania definicji efektywności jako „stanu optymalnego wykorzystania zasobów".

W jego ocenie dużo ważniejsze jest dobre zdefiniowanie ,efektu (wyniku wykorzystania zasobów”, odczuwanego przez świadczeniobiorców, a nie przez świadczeniodawców. Zwraca też uwagę na brak jednolitej miary efektywności (Misiąg, 2005, s. 2).

B. Guziejewska wprost wskazuje na relację pomiędzy efektywnością systemu finansów a użytecznością społeczną. W zaproponowanej definicji stwierdza (Sochacka-Krysiak, 2009, s. 192):

„(...) efektywność systemu finansów to takie ukształtowanie wydatków publicznych, które przy ich danym poziomie pozwala osiągać maksymalną użyteczność społeczną (...)".

Rozważając aspekt korzyści świadczeniobiorcy i użyteczności społecznej, dochodzimy do efektywności społecznej.

I. Rudawska, wskazując na efektywność społeczną jako jeden z trzech wymiarów efektywności w kontekście ochrony zdrowia, odnosi ją do stopnia realizacji zadań społecznych stawianych przed systemami opieki zdrowotnej. 
W tym kontekście wymienia podnoszenie ogólnej zdrowotności pacjentów objętych opieką oraz wzrost dostępności i jakości opieki zdrowotnej (Rudawska, 2011, s. 141).

P. Swider wskazuje, że podstawowym zadaniem systemu opieki zdrowotnej jest skuteczne zapewnienie różnych jej form w sposób efektywny, czyli taki, który pozwoli na swobodny i równy dostęp do usług medycznych przy jednoczesnym zdefiniowaniu ich kosztów i zakresu w sposób dający możliwość ich sfinansowania ze zgromadzonych w określonym trybie środków (Świder, 2004, s. 7-8).

$\mathrm{Z}$ punktu widzenia interwencji medycznej można wyodrębnić dwa ujęcia efektywności. W jednym efektywność utożsamiana jest wyłącznie $\mathrm{z}$ pozytywnym wpływem interwencji medycznej. W drugim jest przedstawiana jako wypadkowa skuteczności i bezpieczeństwa. Stąd jest miarą skuteczności interwencji i bezpieczeństwa zastosowania interwencji. W tym ujęciu o efektywnej interwencji możemy mówić, jeżeli stosunek skuteczności do potencjalnego ryzyka związanego $\mathrm{z}$ zastosowaniem interwencji wypada znacząco na korzyść skuteczności. W tym zakresie rozróżnia się efektywność eksperymentalną i praktyczną (Niżankowski, 2002, s. 12-13).

$\mathrm{Na}$ koniec pozostaje kryterium instytucjonalne (organizacyjne). J. Kudła uznaje, że efektywność organizacyjna jest „najprostsza pojęciowo" (Capiga, 2009, s. 45):

„(...) jeżeli uznamy istnienie celów organizacji (...), wówczas możemy przyjąć, że efektywność jest stopniem, w jakim organizacja realizuje swoje cele (...)."

Konkludując, autor proponuje rozpatrywać efektywność płatnika:

1) indywidualnie - przez właściwą realizację zakładanych zadań (aspekt organizacyjny) przy adekwatnych kosztach (aspekt ekonomiczny),

2) systemowo - przez wzajemną korelację wyników działania Funduszu i pozostałych elementów systemu ochrony zdrowia (aspekt społeczny i medyczny).

W praktyce możliwe są następujące scenariusze:

1) Fundusz wykazuje efektywność na poziomie instytucji przy jednoczesnym braku efektywności systemowej;

2) Fundusz nie wykazuje efektywności na poziomie instytucji i na poziomie systemu;
3) Fundusz wykazuje efektywność na poziomie instytucji i na poziomie systemu.

\section{Charakterystyka Narodowego Funduszu Zdrowia}

Zasady funkcjonowania, organizacja i zakres działania Narodowego Funduszu Zdrowia zostały określone w ustawie $\mathrm{z}$ dnia 27 sierpnia 2004 r. o świadczeniach opieki zdrowotnej finansowanych ze środków publicznych (dalej: ustawa o świadczeniach) ${ }^{3}$.

Fundusz jest państwową jednostką organizacyjną, majaca osobowość prawną. W jego skład wchodzą: centrala Funduszu i oddziały wojewódzkie.

Organami Funduszu są:

1) Rada Funduszu,

2) Prezes Funduszu,

3) rady oddziałów wojewódzkich Funduszu,

4) dyrektorzy oddziałów wojewódzkich Funduszu.

Do zakresu działania Funduszu należą w szczególności:

1) finansowanie świadczeń opieki zdrowotnej udzielanych osobom uprawnionym na podstawie ustawy o świadczeniach;

2) prowadzenie rozliczeń w zakresie określonym w ustawie $\mathrm{z}$ dnia 12 maja 2011 r. o refundacji cen leków, środków spożywczych specjalnego przeznaczenia żywieniowego oraz wyrobów medycznych (dalej: ustawy o refundacji); ${ }^{4}$

3) określanie jakości i dostępności oraz analiza kosztów świadczeń opieki zdrowotnej w zakresie niezbędnym dla prawidłowego zawierania umów o udzielanie świadczeń opieki zdrowotnej;

4) przeprowadzanie konkursów ofert, rokowań i zawieranie umów o udzielanie świadczeń opieki zdrowotnej, a także monitorowanie ich realizacji i rozliczanie;

5) finansowanie medycznych czynności ratunkowych;

6) wdrażanie, realizowanie, finansowanie, monitorowanie, nadzorowanie i kontrolowanie programów zdrowotnych;

7) wykonywanie zadań zleconych, w tym finansowanych przez ministra właściwego do spraw zdrowia, w szczególności realizacja programów zdrowotnych;

8) monitorowanie ordynacji lekarskich;

9) promocja zdrowia;

10) prowadzenie Centralnego Wykazu Ubezpieczonych w celu: 


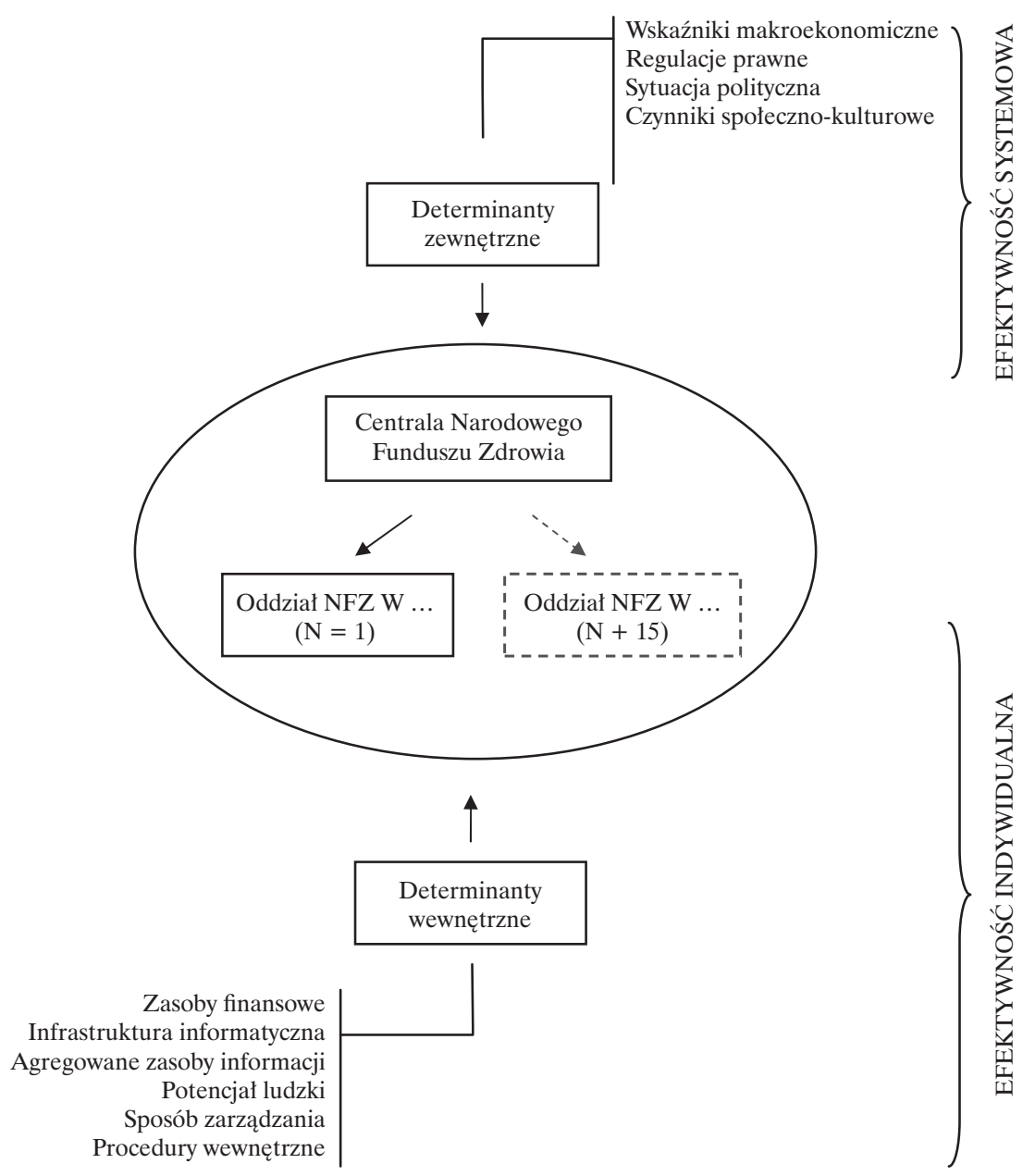

a) potwierdzenia prawa do świadczeń $\mathrm{z}$ ubezpieczenia zdrowotnego

b) gromadzenia danych o ubezpieczonych w Funduszu,

c) gromadzenia danych o osobach uprawnionych do świadczeń opieki zdrowotnej na podstawie przepisów o koordynacji,

d) wydawania poświadczeń i zaświadczeń w zakresie swojej działalności

e) rozliczania kosztów świadczeń opieki zdrowotnej, w tym udzielanych na podstawie przepisów o koordynacji;

11) prowadzenie wydawniczej działalności promocyjnej i informacyjnej w zakresie ochrony zdrowia;

Fundusz nie może wykonywać działalności gospodarczej i być właścicielem pod- miotów wykonujących działalność leczniczą w rozumieniu ustawy z dnia 15 kwietnia 2011 r. o działalności leczniczej5. Środki finansowe Funduszu są środkami publicznymi. Podstawę prowadzenia gospodarki finansowej Funduszu stanowi roczny plan finansowy Funduszu, który co do zasady powinien być zrównoważony w zakresie przychodów i kosztów.

Plan finansowy sporządzany jest w podziale na:

1) planowane koszty dla Centrali, w tym:

a) koszty finansowania działalności centrali,

b) rezerwa na koszty realizacji zadań wynikających z przepisów o koordynacji,

2) planowane koszty poszczególnych oddziałów wojewódzkich Funduszu, w tym: 
a) koszty finansowania działalności poszczególnych oddziałów,

b) rezerwa na koszty świadczeń opieki zdrowotnej w ramach migracji ubezpieczonych,

c) rezerwa, o której mowa w ustawie o refundacji.

Odrębną pozycję stanowią łączne przychody i koszty Funduszu.

Szczegółowe zasady prowadzenia gospodarki finansowej Funduszu, w tym również zasady tworzenia planu finansowego, określa rozporządzenie z dnia 31 maja $2005 \mathrm{r}$. w sprawie szczegółowych zasad prowadzenia gospodarki finansowej Narodowego Funduszu Zdrowia ${ }^{6}$.

Do źródeł przychodów Funduszu zalicza:

1) należne składki na ubezpieczenie zdrowotne,

2) odsetki od nieopłaconych w terminie składek na ubezpieczenie zdrowotne,

3) darowizny i zapisy,

4) dotacje, w tym dotacje celowe przeznaczone na zadania wskazane w ustawie o świadczeniach,

5) środki przekazane na realizację zadań zleconych w zakresie określonym w ustawie o świadczeniach,

6) środki uzyskane z tytułu roszczeń regresowych,

7) przychody z lokat,

8) kwoty w zakresie określonym w ustawie o refundacji,

9) inne przychody.

Środki finansowe Funduszu mogą pochodzić również z kredytów i pożyczek. się:

Do katalogu kosztów Funduszu zalicza

1) koszty świadczeń opieki zdrowotnej dla uprawnionych na podstawie ustawy o świadczeniach,

2) koszty refundacji określone ustawą o refundacji,

3) koszty zadań zleconych, w zakresie określonym w ustawie o świadczeniach,

4) koszty działalności Funduszu, w szczególności koszty amortyzacji, koszty związane z utrzymaniem nieruchomości, koszty wynagrodzeń wraz z pochodnymi, diet i zwroty kosztów podróży,

5) koszty poboru i ewidencji składek na ubezpieczenie zdrowotne,

6) koszt wypłaty odszkodowań,

7) inne koszty wynikające $z$ odrębnych przepisów.
Środki finansowe Funduszu moga być przeznaczone również na spłatę kredytów i pożyczek.

Fundusz realizuje zadania/cele poprzez następujące instrumenty:

1) planowanie finansowe (w tym algorytm podziału środków),

2) kontraktowanie świadczeń opieki zdrowotnej,

3) techniki rozliczania świadczeń opieki zdrowotnej (Jednorodne Grupy Pacjentów, punkty, osobodzień, stawka kapitacyjna, ryczałt).

\section{Percepcja działania NFZ z perspektywy interesariuszy systemu}

Do interesariuszy autor zalicza: pacjentów (świadczeniobiorców), środowisko lekarzy, podmioty wykonujące działalność leczniczą (świadczeniodawców) oraz partie polityczne.

Według badań Centrum Badań Opinii Społecznej w marcu 2012 zdecydowana większość Polaków (78\%, spadek o 5 punktów proc. w stosunku do lutego) krytycznie wypowiadała się o działalności Funduszu (Ocena instytucji publicznych..., 2012, s. 8), przy czym w perspektywie okresu od stycznia 2010 do marca 2012 negatywne oceny utrzymywały się na podobnym wysokim poziomie (ibidem).

Gdy wpiszemy w wyszukiwarkę Google zdanie: „NFZ działa dobrze”, otrzymujemy 8 wyników. Oto fragment jednego $\mathrm{z}$ wpisów na forum:

„(...) Poważnie sądzisz, że NFZ działa dobrze? To chyba jesteś jedyną osobą, jaką znam, która tak twierdzi (...)"”.

Jaki jest przekaz mediów o działalności NFZ? Jaka powinna być ich rola w kreowaniu postrzegania płatnika?

Niekoniecznie jest to przekaz ukierunkowany na edukację pacjenta ${ }^{8}$, a raczej sformatowany zgodnie $\mathrm{z}$ ogólnym trendem nastawionym na krytykę NFZ.

Poniżej znajdują się fragmenty przykładowych przekazów (artykułów/wypowiedzi):

„(...) Biurokracja NFZ wykańcza chorych. NFZ żąda, by każdy chory osobiście zgłaszał się z wnioskiem na wydanie wózka inwalidzkiego (...) w jego biurze. Chodzi o tysiące pacjentów (...)" (Watoła, http). 
„(...) Narodowy Fundusz Zdzierców. Na 100 zł oszukali każdego Polaka pracownicy służby zdrowia w 2004 r. (...)" (Konarska, http).

„(...) Pacjenci czekają, łóżka stoją puste (...) Zakład Pielęgnacyjno-Opiekuńczy od zaraz mógłby przyjąć 50 oczekujących na to pacjentów. Nie przyjmie, bo Narodowy Fundusz Zdrowia za nich nie zapłaci (...)"9.

„(...) Żarty żartami, ale pacjentom do śmiechu nie jest. Na sam widok logo NFZ cierpnie im skóra, więc i zdrowo uśmiechnięta twarz Jacka Paszkiewicza na pewno humoru im nie poprawia (...)"10.

„(...) Nawet tysiąc Polaków umiera rocznie na raka nerki. Szansę na życie odbierają im bezduszne urzędasy z Ministerstwa Zdrowia i NFZ (...)"11.

„(...) NFZ zabija pacjentów. »Fakt« podaje, że dyrektor bydgoskiego szpitala walczy o życie 230 chorych. Zawiadomił prokuraturę, że NFZ chce ich zabić, nie dając pieniędzy na leki - pisze gazeta. Oskarżam: to, co wyprawia NFZ to planowa eutanazja chorych - mówi dyrektor bydgoskiego szpitala im. Jurasza (...)"12.

„(...) Protestujący przynieśli ze sobą m.in. transparenty z napisami »Narodowy Fundusz Zdrowia przyczynia się do likwidacji szpitali«, »Zlikwidować $\mathrm{NFZ}$ « (...) domagają się rozmowy z dyrektorem NFZ w Białymstoku. Zarzucają mu lekceważenie pacjentów i doprowadzanie do upadku szpitali (...)."13

Tego typu informacje tworzą i jednocześnie podtrzymują powszechne przekonanie, że gdyby nie NFZ, to służba zdrowia byłaby co najmniej bliska ideałowi.

Jak zauważa M. Balicki, za wykreowanie negatywnej percepcji o Funduszu odpowiadają nie tylko media tabloidowe, ale również politycy, którzy często bez znajomości tematu oceniają, to, co się dzieje w ochronie zdrowia (Sienkiewicz 2011, s. 12).

Dlatego nie można zapominać o perspektywie oceny/odczuć pacjentów w kontekście ich determinantów, czyli na ile są ukształtowane przez ,agenta" lekarza/ świadczeniodawcę (problem możliwej różnicy/rozbieżności interesów) lub polityków i media.

Ponadto konieczne jest uwzględnienie płaszczyzn konfliktów między środowiskiem lekarzy/świadczeniodawcami a Funduszem. Możemy wyodrębnić naturalne pola konfliktów wynikające $\mathrm{z}$ różnicy interesów oraz pola możliwe do zniwelowania.
Dla przykładu: kwestia liczby i czestotliwości wydawanych przez Prezesa NFZ zarządzeń regulujących zasady finansowania i rozliczania świadczeń opieki zdrowotnej (problem ilości i stabilności przyjętych rozwiązań $)^{14}$ :

„(...) NFZ znowu zmienia zasady kontraktowania usług medycznych (...) nie można zmieniać wymogów w listopadzie, jeśli mają one obowiązywać od stycznia (...) Po drugie wprowadzanie nowych wymogów musi wiązać się z odpowiednio długim okresem przejściowym, żeby każdy szpital miał możliwość dokonania niezbędnych inwestycji i dostosowania się do wymogów (...)".

W opinii J. Paszkiewicza, byłego Prezesa NFZ naturalną cechą Funduszu jest „wewnętrzny i zewnętrzny konflikt, stanowiący jego naturalne otoczenie (Uniknąć chaosu..., 2008, s. 9).

W kontekście percepcji pojawiają się pytania: czy w sposób prawidłowy Fundusz komunikuje się $\mathrm{z}$ interesariuszami? Jak kreowana jest polityka informacyjna, polityka wizerunkowa?

Dla przykładu M. Pasek zwrócił uwagę na stosunkowo niewielką liczbę odsłon stron NFZ, co tłumaczy głównie hermetycznym językiem, jakim posługuje się Fundusz (Pasek, 2011, s. 27). Teoretycznie, uwzględniając zawartość merytoryczną tych stron, powinny być one jednym $\mathrm{z}$ podstawowych źródeł informacji dla pacjentów. Znamienne jest również, że pacjenci (i nie tylko), artykułując swoje potrzeby i zastrzeżenia co do ochrony zdrowia, często jeszcze posługują się słowem „kasy”.

Nie bez znaczenia jest też brak upowszechnienia wiedzy o kosztach udzielania świadczeń opieki zdrowotnej (chociażby jaki jest średni koszt hospitalizacji). Stąd liczne „dywagacje pacjentów” w stylu „gdybym sam odkładał...”.

Zapomina się przy tym o zasadzie solidaryzmu.

Dla przykładu w 2011 r. Fundusz poniósł roczne koszty leczenia przekraczające 100 tys. zł na osobę na rzecz 13.815 pacjentów, którzy stanowili tylko $0,0373 \%$ populacji Polaków (Finansowanie..., 2012, s. 3).

Prawie w większości rodzajach świadczeń opieki zdrowotnej koszty leczenia mężczyzn przewyższają koszty leczenia kobiet (Analiza korzystania..., 2010, s. 26). Niestety tego typu informacje nie trafiaja do większości pacjentów. 


\section{Zmiany instytucjonalne i systemowe w zakresie działania NFZ}

W praktyce zabezpieczenie zdrowotne może być zorganizowane $\mathrm{w}$ następujący sposób ${ }^{15}$ :

1) na poziomie organów ( - i przez) administracji rządowej (w tym administracji rządowej w województwie),

2) na poziomie organów ( - i przez) JST,

3) organizacja zabezpieczenia zdrowotnego w oparciu o jedną instytucję publiczną,

4) organizacja zabezpieczenia zdrowotnego w oparciu o kilka (np. 16) instytucji publicznych nie konkurujących między sobą (z mechanizmem nadzoru i koordynacji),

5) organizacja zabezpieczenia zdrowotnego w oparciu o kilka (np. 16) instytucji publicznych konkurujących między sobą (z mechanizmem nadzoru i koordynacji),

6) organizacja zabezpieczenia zdrowotnego w oparciu o kilka instytucji publicznych i podmiotów komercyjnych konkurujących między sobą (z mechanizmem nadzoru i koordynacji).

Instytucje pełniące funkcje płatnika trzeciej strony można podzielić według następujących kryteriów (Więckowska, 2010, s. 12-22):

a) liczby,

b) formy własności,

c) zasięgu terytorialnego,

d) podmiotu i przedmiotu ochrony,

e) wyceny i wyrównywania ryzyka,

f) powiązania $z$ innym podmiotami,

g) swobody zawierania umów ze świadczeniodawcami.

Możliwa jest też organizacja zabezpieczenia zdrowotnego bez płatnika trzeciej strony. Rozwiązaniem alternatywnym są medyczne konta oszczędnościowe oparte na finansowaniu kapitałowym (Oska, http).

\section{Czy konieczna jest konkurencja pomiędzy płatnikami?}

W ramach badań ankietowych przeprowadzonych przez J. Owoca na pytanie, czy powinny istnieć fundusze zdrowia alternatywne wobec NFZ, pozytywnie odpowiedziało $68,5 \%$ badanych. Wysoki odsetek odnotowano bez względu na wiek respondentów, ich wykształcenie, zamieszkanie lub stan zdrowia (Owoc, 2009, s. 119, 127).
W przypadku przedsiębiorców zdecydowana ich większość, bo aż $74 \%$ ankietowanych, chciałoby konkurencji między towarzystwami ubezpieczeniowymi, co w konsekwencji miałoby oznaczać złamanie monopolu NFZ (Sondaż..., 2011).

Postulat budowania systemu, który docelowo pozwalałby na przejmowanie zadań powszechnego ubezpieczenia zdrowotnego przez konkurujących ubezpieczycieli publicznych i niepublicznych znalazł się pośród rekomendacji Konferencji „Białego Szczytu" - z zastrzeżeniem, że powinien być to system oparty na zasadach solidaryzmu społecznego (Rekomendacje..., http).

Wprowadzenie konkurencji między płatnikami, publicznymi i prywatnymi, w tym w zakresie świadczeń gwarantowanych, proponował również Rzecznik Praw Obywatelskich ${ }^{16}$.

O konkurencji jako jedynej metodzie zwiększenia efektywności systemu pisała była minister zdrowia, E. Kopacz (2011, s. 14):

„(...) System w obszarze płatnika jest dzisiaj
zbudowany wokół alokacji zasobów, a nie
wokół dbania o poziom satysfakcji pacjenta.
W efekcie mamy nieefektywnie wydawane
pieniądze, kolejki i źle obsługiwanych cho-
rych. Konkurencja jest jedyną metodą zwięk-
szenia efektywności systemu (...).”

Pod koniec lutego 2012 roku B. Arłukowicz, obecny minister zdrowia, przemawiając na Nadzwyczajnym XI Zjeździe Lekarzy również zapowiedział rozpoczęcie dyskusji o wprowadzeniu konkurencji dla płatnika.

W jego odczuciu wprowadzenie konkurencji Funduszu jest jednym z najbardziej oczekiwanych rozwiązań w ochronie zdrowia, które poprawi system dla pacjenta i lekarza ${ }^{17}$.

Kilka dni później na początku marca 2012 roku doprecyzowal, iż trwają prace nad projektami ustaw wprowadzających dodatkowe ubezpieczenia zdrowotne i konkurencję dla NFZ: ${ }^{18}$

„(...) Chodzi o to, aby to pacjent decydował, czy jego świadczenia medyczne sfinansuje Fundusz, czy też inny platnik (...) Nie możemy dopuścić do tego, aby NFZ został płatnikiem tylko dla najmniej zamożnych i najciężej chorych (...) Konieczne jest jednak zbudowanie strategii utworzenia i wprowadzenia do systemu konkurencji dla płatnika publicznego. Ta konkurencja poprawi jakość świadczeń zdrowotnych (...)”. 
Z kolei w wypowiedzi pod koniec kwietnia 2012 roku minister zdrowia zapowiedział zmianę działania NFZ ${ }^{19}$.

Wiceprezes Naczelnej Rady Lekarskiej K. Radziwiłł, komentując wspomniane już wystąpienie B. Arłukowicza na Nadzwyczajnym XI Zjeździe Lekarzy, stwierdził: ${ }^{20}$

„(...) lekarze nie usłyszeli (...) niczego nowego od ministra zdrowia (...) zapowiedzi wprowadzenia konkurencyjnego dla Narodowego Funduszu Zdrowia płatnika za świadczenia medyczne słyszeli od paru ministrów zdrowia $(\ldots)$

Z tych „paru” ministrów tylko wspomniana już E. Kopacz przedstawiła stosowny projekt ustawy.

Zakładał on utworzenie siedmiu konkurujących ze sobą Towarzystw Ubezpieczenia Zdrowotnego (TUZ) z siedzibą w: Gdańsku, Katowicach, Krakowie, Łodzi, Poznaniu, Warszawie, Wrocławiu. Powołując się na dotychczasowe doświadczenia, przyjęto rozwiązanie, w którym każda $\mathrm{z}$ instytucji powszechnego ubezpieczenia zdrowotnego miała skupiać co najmniej $10 \%$ ogółu osób ubezpieczonych w Polsce. Zmiany miały następować w trzech etapach (Projekt $z$ dnia. 31 lipca 2008..., http):

1) podział NFZ na publiczne instytucje powszechnego ubezpieczenia zdrowotnego (przejście od systemu płatnika monopolisty do systemu kilku płatników),

2) kontraktowanie przez instytucje powszechnego ubezpieczenia zdrowotnego świadczeń opieki zdrowotnej na terenie całego kraju,

3) możliwość udziału w powszechnym ubezpieczeniu zdrowotnym płatników niepublicznych.

W ramach konsultacji do projektu zgłoszono dużą liczbę uwag zastrzeżeń (Odpowiedź..., http). Marszałkowie województw solidarnie opowiedzieli się przeciwko likwidacji oddziałów Narodowego Funduszu Zdrowia (Szparkowska, http). W Sejmie złożono w tym zakresie interpelacje poselskie. W konsekwencji projekt nie został skierowany do Sejmu. Za komentarz, moga posłużyć słowa J. Szulca, Sekretarza Stanu w Ministerstwie Zdrowia (co dalej $z$ NFZ, http):

„(...) Poprosiłem panią minister Ewę Kopacz, aby zlecić dodatkową analizę obecnego funkcjonowania w Polsce ubezpieczeń zdrowotnych oraz dotyczącą modelu najbardziej optymalnego w naszych warunkach.
Potrzebujemy takich ekspertyz, gdyż jednym z głównych problemów polskiego systemu ochrony zdrowia jest podejmowanie decyzji bez pełnego przygotowania informacyjnego (...)".

„(...) Rodzą się dwa zasadnicze pytania: czy projektowany podział NFZ spowoduje lepszą dostępność do świadczeń, oraz czy uruchomi konkurencję? I tu kolejna wątpliwość: czy takie towarzystwa będą w stanie ze sobą konkurować, mając do zaoferowania ten sam produkt? (...)."

W trakcie dyskusji o podziale/likwidacji Funduszu S. Golinowska wprost określiła podział NFZ jako pomysł niedobry wręcz szkodliwy. Za nieporozumienie uznała uzasadnianie podziału wprowadzeniem konkurencji między publicznymi płatnikami (Wojteczek, 2008, s. 30):

„(...) Co ma bowiem być przedmiotem tej konkurencji: różna składka, inny koszyk świadczeń gwarantowanych, czy może chodzi o wzrost możliwości wyboru dla pacjenta? Na przykład pacjent $\mathrm{z}$ Tarnowa zapisze się do bardziej konkurencyjnego płatnika, który będzie miał siedzibę nad morzem? (...).”

W ocenie S. Golinowskiej NFZ jest instytucją potencjalnie warunkującą racjonalne gospodarowanie środkami 21 .

$\mathrm{W}$ jednym $\mathrm{z}$ wywiadów stwierdziła (Rynek w ochronie..., http):

„(...) w działania Funduszu trzeba ingerować wówczas, gdy nie przestrzega zasad związanych $\mathrm{z}$ istotą ubezpieczenia społecznego (dostępności i sprawiedliwości), pozostaje w niezgodzie z etyką, jest niegospodarny i nie kieruje się kryteriami jakości usług medycznych (...)"

$\mathrm{Na}$ problem konkurencji, a konkretnie terytorialności, zwrócił uwagę M. Kautsch (NFZ - dzielić..., 2007, s. 26):

„(...) Od momentu ogłoszenia przez Ministerstwo Zdrowia woli podziału NFZ zastanawiam się, czemu ma służyć ta operacja. Jeżeli ma być tylko podziałem terytorialnym, to rodzi się pytanie, po co to w ogóle robić. Jeżeli zaś ma sprawić, że fundusze zaczną działać w całym kraju, co doprowadzi do konkurencji między płatnikami, taki pomysł wydaje się bardziej trafiony (...) Terytorialność Funduszu będzie ogromną komplikacją dla zakładów świadczących usługi dla mieszkańców różnych województw (...)."

J. Sobiech pytanie, czy wybór rynkowy można odnosić do płatnika określa mianem kontrowersyjnego. Za oczywistą uznaje 
konieczność reglamentacji opieki zdrowotnej (Rój i Sobiech, 2006, s. 25).

Konkurencja, co do zasady, powinna sprzyjać efektywnemu wykorzystaniu zasobów pieniężnych.

Analizując rynek usług zdrowotnych, I. Rudawska wskazała na trzy obszary zaistnienia konkurencji (Rudawska 2003, s. 153):

1) stronę podażową (konkurencja wśród świadczeniodawców o dostęp do publicznych środków finansowych, konkurencja o pacjenta),

2) stronę popytową (konkurencja wśród pacjentów o dostęp do usług określonych świadczeniodawców i o określonej jakości),

3) mechanizm alokacji (konkurencja wśród ubezpieczycieli o dostęp do zasobów finansowych przeznaczanych na ubezpieczenie zdrowotne).

W opinii B. Więckowskiej w ochronie zdrowia powinna funkcjonować konkurencja „mniej lub bardziej” regulowana (Regulowana konkurencja..., 2012, s. 34). Zwraca też uwagę, iż konkurencja nie może być celem samym w sobie, a jej wprowadzenie wymaga odpowiedniego przygotowania (ibidem).

Analizując holenderski systemu zabezpieczenia zdrowotnego, autorka wymienia dziewięć warunków do uzyskania poprawy efektywności systemu poprzez wprowadzenie konkurencji (Więckowska, 2010, s. 57):

1) możliwość wyboru płatnika,

2) sprawny system wyrównywania ryzyka,

3) swoboda zawierania umów ze świadczeniodawcami,

4) przejrzystość systemu,

5) dostęp pacjenta do informacji,

6) bodźce finansowe skłaniające do efektywności,

7) ograniczenie efektu gapowicza,

8) warunki umożliwiające kontestowalność rynków,

9) sprawny nadzór regulacyjny systemu

Traktowanie konkurencji w ochronie zdrowia ze szczególną ostrożnością zalecają B. Adamczyk-Kloczkowska i M. Wojna. Piszą (Adamczyk-Kloczkowska i Wojna, 2008, s. 60):

„(...) konkurencja nie stanowi wartości samej w sobie, ale jest tylko jednym $\mathrm{z}$ instrumentów osiągania społecznie pożądanych celów (...).”

Zadają też ważne pytanie, na ile wprowadzenie $\mathrm{w}$ ochronie zdrowia prokonku- rencyjnych zmian ,jest w stanie stłumić presję popytową" (ibidem, s. 64).

$\mathrm{Na}$ specyfikę rynku usług medycznych zwraca też uwage W. Misiński. Jednocześnie postuluje potrzebę konkurencji w ochronie zdrowia. Wspomina o trzech rodzajach rynków, opartych na wolnym wyborze kontrolowanym przez państwowe agencje (Ile rynku..., http).

O niesprawności mechanizmu rynkowego na rynku usług medycznych wspomina E. Nojszewska (2005, s. 310):

„(...) Na rynku usług medycznych i ubezpieczeń medycznych niesprawność mechanizmu rynkowego jest szczególnie silna i prowadzi do poważnych konsekwencji (...)”.

Wprowadzenie konkurencji jako fundamentalnego warunku ograniczenia kosztów funkcjonowania ochrony zdrowia proponuje W. Smith, amerykański prawnik zajmujący się problematyką ochrony zdrowia. Nie uznaje jednak USA za wzór w tym zakresie.

Dostrzega bowiem, że „komercyjna logika w służbie zdrowia staje się coraz bardziej bezwzględna" (Bielecki, 2011).

Dla odmiany K. Szewczyk za konieczne we współczesnej opiece zdrowotnej uznaje nierynkowe racjonowanie ekonomiczne. Rozpatruje problem w kategoriach moralnych (Szewczuk, 2005, s. 95-96):

„(...) Moralna zgoda na racjonowanie ekonomiczne (...) wymaga istotnej zmiany w organizacji medycyny. Na szczeblu instytucjonalnym trzeba ją poddać kontroli „trzeciej strony" - głównie płatnika i społeczeństwa (...) W Polsce zmiany te już się częściowo dokonują - jednak przy wyraźnym oporze i niechęci środowiska lekarskiego, szczególnie gdy chodzi o kontrole na szczeblu instytucjonalnym, która obecnie usiłuje sprawować Narodowy Fundusz Zdrowia (....).”

Poniżej zaprezentowano przykładowe obszary konkurencji w relacji płatnik- świadczeniodawca i płatnik-świadczeniobiorca.

Autor z dużą rezerwą pochodzi do wprowadzenia konkurencji w obszarze ceny za świadczenia opieki zdrowotnej. Aczkolwiek pozostawia do rozważenia tego typu rozwiązanie, ale tylko do wybranych procedur lub rodzajów, np. podstawowej opieki zdrowotnej.

W przypadku konkurencji przez jakość świadczeń opieki zdrowotnej zwraca uwagę na problem zobiektywizowania skali różnicującej świadczeniodawców. W punkcie wyjścia każdy świadczeniodawca powinien 
spełniać wymagania dotyczace zarówno kwalifikacji personelu (umiejętności, doświadczenia), jak i wyposażenia w sprzęt i aparaturę medyczną. W kontekście konkurencji jakościa pojawia się też pytanie: a co ze standaryzacją?

Przykładowym elementem różnicującym w tym zakresie może być atmosfera (w tym warunki), w jakiej świadczenia opieki zdrowotnej są realizowane (Cichońska i Fiks, 2008, s. 14-15).

Innym z kryterium może być czasu oczekiwania na świadczenie opieki zdrowotnej. $\mathrm{Z}$ badań przeprowadzonych w marcu 2012 przez TNS OBOP na zlecenie organizatorów konkursu „Zdrowy Szpital” wynika, że dla ponad połowy Polaków (57\%) najważniejszy w opiece szpitalnej jest krótki czas oczekiwania na zabiegi/wizytę. W dalszej kolejności respondenci (44\%) wskazali na jakość obsługi pacjenta ${ }^{22}$.

Do rozważenia pozostaje konkurencja wysokością składki. Na ten czynnik, jako podstawową przyczynę decyzji ubezpieczonych o zmianie kasy chorych, zwraca uwagę C. Włodarczyk, analizując problem konkurencji w Niemczech (Włodarczyk, http):

„(...) Wstępne oceny pozwalają sądzić, że w ciaggu roku od $3 \%$ do $5 \%$ ubezpieczonych zmieniało swój związek z kasą chorych. Stanowiło to istotny sygnał dotyczacy preferencji pacjentów. Od tego czasu nadzieje wiązane ze stosowaniem narzędzi rynkowych znacznie wzrosły. Wobec narastających trudności, przed którymi staje system finansów publicznych oszczędności w sferze wydatków na zdrowie - a do tego ma prowadzić konkurencja między płatnikami - mogą przynieść bardzo pozytywne efekty (...)."

Inni zwracają uwagę na iluzoryczny charakter konkurencji między kasami chorych w Niemczech. Podkreślają, iż koszty związane $\mathrm{z}$ utrzymaniem dużej liczby płatników i tym samym możliwość wyboru przez świadczeniobiorcę nie są rekompensowane przez wzrost jakości (Bułanowski, 2010, s. 27).

\section{Podsumowanie}

W niniejszym artykule autor przedstawił pewien sposób postrzegania efektywności płatnika. Świadomie jednak nie udzielił jednoznacznej odpowiedzi na pytanie o konkurencyjność na poziomie płatnika. Co najwyżej, zasygnalizował pewne wątpliwości i zadał pytania. Pozostawia do rozstrzygnięcia kwestię, czy obecnie, zakła- dając etapowość zmian, nie ograniczyć się tylko do konkurencji po stronie podażowej.

Natomiast przekonany jest co do istnienia przesłanek dających możliwość zwiększenia potencjału ${ }^{23}$ Funduszu.

Dlatego za konieczne uznaje podjęcie działań mających na celu identyfikację dysfunkcji i zaprojektowanie stosowanych zmian zarówno na poziomie instytucji (m.in. przypisanie obecnej Centrali NFZ funkcji nadzoru/koordynacji) jak i w otoczeniu (m.in. utworzenie Agencji Taryfikacji Kosztów). W tym zakresie warto dokonać przeglądu rozwiązań będących propozycją zmian w zakresie funkcjonowania płatnika.

Rekomendacje co do ram organizacyjnych, w jakich ma działać płatnik, zostały zawarte m. in. w dokumencie Strategia zmian $w$ systemie opieki zdrowotnej. Szansa przezwyciężenia kryzysu. ${ }^{24}$

$\mathrm{Na}$ uwagę zasługuje również opracowanie Pożadane kierunki zmiany systemu ochrony zdrowia $w$ Polsce. Między racjonowaniem i racjonalizacja (Golinowska, 2004).

Kompleksową propozycją zmian stanowił Projekt ustawy o powszechnym ubezpieczeniu zdrowotnym zaprezentowany przez Ogólnopolski Związku Zawodowego Lekarzy. ${ }^{25}$

Innym przykładem zmian na poziomie płatnika jest propozycja przekształcenia oddziałów NFZ w działające na poziomie samorząu instytucje rozliczeniowo-finansowe (Zdrowotne Izby Obrachunkowo-Rozliczeniowe). Działalność tego typu instytucji byłaby oparta na jednolitych taryfikatorach, procedurach i standardach. Ich zadaniem byłoby administrowanie przekazanymi zasobami (składki ubezpieczeniowe, środki $\mathrm{z}$ budżetów JST lub budżetu państwa) (Dercz, 2005).

Ostatnio w mediach pojawiała się propozycja połączenia ZUS i NFZ. Pomysł nie skonkretyzowany. Cel to ograniczenie kosztów ściągania i administrowania składką zdrowotną (Łaczenie ZUS..., http). Pomysł alternatywny to całkowite wyłączenie ZUS $\mathrm{z}$ poboru składki zdrowotnej i skierowanie jej bezpośrednio do NFZ (ibidem). W ocenie autora - propozycja zasadna.

\section{Przypisy}

1 W tym również w dokumentach programowych. Dla przykładu w strategii Sprawne Państwo 2011-2020 postuluje się podjęcie kompleksowych działań zmierzających do poprawy efek- 
tywności sytemu ochrony zdrowia. Zob. Strategia „Sprawne Państwo” (2011, s. 83).

2 Zarówno w literaturze, jak i w języku potocznym często pojęcie efektywności jest utożsamiane ze skutecznością. Zob. Gorzeń-Mitka (2005, s. 138-140); Krzemień i Wolnika (http).

3 Wcześniej NFZ działał na podstawie Ustawy z dnia 23 stycznia 2003 r. o powszechnym ubezpieczeniu w Narodowym Funduszu Zdrowia (Dz.U. Nr 45, poz. 391 ze zmianami). Większość przepisów tej ustawy została przy tym uchylona wyrokiem Trybunału Konstytucyjnego z dnia 7 stycznia 2004 (Dz. U. Nr 5, poz. 37). W konsekwencji uchwalono Ustawę z dnia 27 sierpnia 2004 r. o świadczeniach opieki zdrowotnej finansowanych ze środków publicznych. Zob. Baka i in. (s. 36-37).

4 Dz. U. Nr 122, poz. 696.

5 Dz. U. Nr 112, poz. 654 ze zmianami.

6 Dz. U. Nr 104, poz. 875 ze zmianami.

7 http://www.platforma.org/forum/index.php?/ topic/29813-konkurencja-dla-nfz/.

8 Wśród działań naprawczych podejmowanych jeszcze w ramach sytemu opartego na ustawie z dnia 6 lutego 1997 r. o powszechnym ubezpieczeniu zdrowotnym wymienia się m.in. akcję edukacyjną pogłębiającą wiedzę o zakresie kompetencji wszystkich partnerów (czyli interesariuszy), zaangażowanych w kształtowanie ochrony zdrowia w nowym systemie. Zob. Sprawozdanie pełnomocnika (http).

9 http://wiadomosci.gazeta.pl/kraj/1,34309,36 78045.html.

10 http://www.fakt.pl/Szef-NFZ-Jacek-Paszkiewiczprzytyl,artykuly,141577,1.html.

11 http://www.se.pl/wydarzenia/kraj/panstwo-zabi ja-rocznie-1000-chorych-na-raka_95716.html.

12 http://wiadomosci.wp.pl/title,NFZ-zabija-pac jentow,wid,7577773, wiadomosc.html?ticaid= 1 e6a8.

13 http://www.polskieradio.pl/5/3/Artykul/498845, Manifestacja-w-Bialymstoku-Zlikwidowac-NFZ.

14 http://www.pracodawcyrp.pl/aktualnosci/art,7 59,nfz-znowu-zmienia-zasady-kontraktowania -uslug-medycznych.html.

15 Por. Kozierkiewicz (2008, s. 26); Rudawska(2007, s. 21); Morris, Devlin i Parkin (2011, s. 196).

16 III debata publiczna dotycząca warunków ustanowienia nowego systemu ochrony zdrowia gwarantującego właściwe zabezpieczenie praw pacjentów. Konferencja prasowa z udziałem ekspertów. Warszawa, listopad 2007. Pozyskono z: http://www.rpo.gov.pl/pliki/1195736066.pdf.

17 http://www.rynekzdrowia.pl/Polityka-zdrowotna/ XI-Krajowy-Zjazd-Lekarzy-minister-zapowia da-kolejne-reformy-lekarze-gwizdza-i-bucza-na ministra,117290,14.html.

18 http://www.rynekzdrowia.pl/Ubezpieczeniazdrowotne/Minister-Arlukowicz-pacjent-zdecy duje-kto-sfinansuje-jego-swiadczenia,117606,4. html.
19 http://www.rynekzdrowia.pl/Polityka-zdrowo tna/Arlukowicz-trzeba-zmienic-system-kontrak towania-uslug-i-sposob-dzialania-NFZ,119266 ,14.html.

20 http://www.polskieradio.pl/5/3/Artykul/54779 7,Minister-nie-zaskoczyl-lekarzy-nic nowego.

21 http://www.rynekzdrowia.pl/Konferencje/I-Fo rum-Rynku-Zdrowia,59027,1.html.

22 http://zdroweszpitale.pl/p/fakty.

23 Przede wszystkim agregowane zasoby informacji i rozbudowana infrastruktura informatyczna. Nie bez znaczenia jest również posiadany potencjał ludzki, niestety ograniczony w zakresie pracowników z wykształceniem medycznym, oraz istniejące procedury.

24 Opracowanie przygotowane przez Zespól ds. Rozwiązań Systemowych w Ochronie Zdrowia (przewodniczącym zespołu był C. Włodarczyk). Dokument ukazał się w marcu 2004 roku.

25 Projekt został opublikowany w październiku 2005 roku.

\section{Bibliografia}

Adamczyk-Kloczkowska, B. i Wojna, M. (2008). Czynniki wspierające i osłabiające konkurencje w systemie ochrony zdrowia. Zdrowie Publiczne, 118(1).

Analiza korzystania ze świadczeń opieki zdrowotnej w 2009 r. i rozkładu indywidualnych wydatków Narodowego Funduszu Zdrowia związanych z finansowaniem tych świadczeń (2010). Warszawa: Narodowy Fundusz Zdrowia.

Baka, K., Machulak, G., Pietraszewska-Macheta, A. i Sidorko, A. (2010). Ustawa o świadczeniach opieki zdrowotnej finansowanych ze środków publicznych. Komentarz. Warszawa: Wolters Kluwer Polska.

Bielecki, J. (2011). Służba zdrowia musi być płatna. Rozmowa z Wesleyem J. Smithem. Dziennik Gazeta Prawna, 8 kwietnia.

Biznes nie zna języka polskiego (2011). Dziennik Gazeta Prawna, 62.

Bułanowski, R. (2010). Nie wylewać dziecka $\mathrm{z}$ kąpielą. Menedżer Zdrowia, 8 .

Capiga, M. (2009). Determinanty i pomiar efektywności działania banku. w: Harasim, J. (red.), Konkurencyjność i efektywność działania banku - podejście zasobowe. Katowice: Uniwersytet Ekonomiczny.

Cichońska, D. i Fiks, A. (2008). Miejsce jakości usług w zarządzaniu zakładem opieki zdrowotnej. w: Lisiecka-Biełanowicz, M. i Samoliński, B. (red.), Systemy zarzadzania jakościa $w$ ochronie zdrowia. Warszawa: Ministerstwo Zdrowia.

Co dalej z NFZ, czyli likwidacja nie jest przesądzona? Pozyskano z: http://www.rynekzdrowia.pl/Ubezpieczenia-zdrowotne/Co-dalej-z-NFZ-czyli-likwidacjanie-jest-przesadzona,3385,4,drukuj.html. 
Dercz, M. (2005). Samorządowy model ochrony zdrowia. Analizy i Opinie, 43. Warszawa: Instytut Spraw Obywatelskich.

Dubas, K. (2011). Problematyka efektywności w ochronie zdrowia - znaczenie i metody pomiaru. Problemy Zarzadzania, 3.

Finansowanie szczególnie wysokich kosztów leczenia pacjentów w 2011 r. (2012). Warszawa: Narodowy Fundusz Zdrowia.

Golinowska, S. (2004). Pożądane kierunki zmiany systemu ochrony zdrowia $w$ Polsce. Między racjonalizowaniem a racjonalizacja. Warszawa: Centrum Analiz Społeczno-Ekonomicznych.

Gorzeń-Mitka, I. (2005). Skuteczność - próba interpretacji (w:) Efektywność - rozważania nad istotą i pomiarem. w: Dudycz, T. (red.), Efektywność - rozważania nad istotą i pomiarem. Prace Naukowe, 1060. Wrocław: Akademia Ekonomiczna we Wrocławiu.

Ile rynku $w$ ochronie zdrowia (2011) Pozyskano z http://www.rynekzdrowia.pl/Rynek-Zdrowia/Ile -rynku-w-ochronie-zdrowia,112743.html.

Juzwiszyn, J., Rybicki, W. i Smoluk, A. (2005). O Definicji efektywności. Rozważania nad celowością w naturze i rozwojem. w: Dudycz, T. (red.), Efektywność - rozważania nad istotą i pomiarem. Prace Naukowe, 1060. Wrocław: Akademia Ekonomiczna we Wrocławiu.

Konarska, I., Narodowy Fundusz Zdzierców. Pozyskano z: http://www.wprost.pl/ar/80799/NarodowyFundusz-Zdziercow/?I=1189.

Kopacz, E. (2011). System ochrony zdrowia: pacjent w centrum. w: Raport Optymalizacja sytemu ochrony Zdrowia w Polsce: mapa wyzwań. Raport THINKTANK. Warszawa.

Kozierkiewicz, A. (2008). Co nas czeka w ochronie zdrowia - Nostradamus 2009-2011. Menedżer Zdrowia, 10.

Krzemień, E. i Wolnika, R., Ocena efektywności wdrożenia komputerowego oprogramowania wspomagającego zarządzanie jakościa. Pozyskane z: http://keraunos4.republika.pl/2005_1.pdf.

Eqczenie ZUS z NFZ, czyli jak uzdrowić sktadkę na zdrowie. Pozyskano z: http://serwisy.gazetaprawna. $\mathrm{pl} /$ zdrowie/artykuly/565325,laczenie_zus_z_nfz_ czyli_jak_uzdrowic_skladke_na_zdrowie.html.

Matwiejczuk, R. (2000). Efektywność - próba interpretacji. Przeglad Organizacji, 11.

Meredyk, K. (red.) (2007). Ekonomia ogólna. Białystok: Uniwersytet w Białymstoku.

Misiag, W. (2005). Jawność i przejrzystość a aktywność finansów publicznych. Seminaryjne posiedzenie Kolegium NIK. Warszawa, 2005.

Morris, S., Devlin, N. i Parkin, D. (2011). Ekonomia w ochronie zdrowia. Warszawa: Wolters Kluwer Polska.
NFZ - dzielić czy nie dzielić? Sonda redakcyjna (2007) Menedżer Zdrowia, 10.

Niżankowski, R., Bała, M. Broda, M., Dubiel, B., Hetnał, M,. Kawalec, P., Łanda, K., Plisko, R., Podmokły, A., Wcisło, J. i Wójtowicz, E. (2002). Analiza efektywności. Kraków: Uniwersyteckie Wydawnictwo Medyczne VESALIUS.

Nojszewska, E. (2005). Racjonalizacja wydatków na ochronę zdrowia. w: Gluchowskiego, J., Pomorska, A. i Szołno-Koguc, J. (red.), Ekonomiczne i prawne problemy racjonalizacji wydatków publicznych Tom II. Lublin: Uniwersytet Marii Curie-Skłodowskiej.

Nojszewska, E. (2011). Efektywność ekonomiczna jako narzędzie analityczne dla ochrony zdrowia. Problemy Zarzadzania, 3.

Nowak, E. (red.) (1998). Ocena efektywności przedsięwzięć gospodarczych. Wrocław: Wydawnictwo Akademii Ekonomicznej we Wrocławiu.

Ocena instytucji publicznych. Komunikat z badań. Centrum Badania Opinii Społecznej (2012). Warszawa.

Odpowiedź na Interpelacje Poselska Nr 6413. Pozyskano z: http://orka2.sejm.gov.pl/IZ6.nsf/ main/1C8F0981.

Osak, M., Medyczne konta oszczędnościowe a finansowanie opieki zdrowotnej. Pozyskano: http://spole cznieodpowiedzialni.pl/files/file/07ndig0tsxrjf66v2e65gnw09718jf.pdf.

Owoc, S. (2009). Narodowy Fundusz Zdrowia w warunkach konkurencji, prywatyzacja a dostęp do usług zdrowotnych - wyniki badań ankietowych. Wiadomości Ubezpieczeniowe, 4.

Pasek, M. (2011). Funduszowy żargon. Menedżer Zdrowia, 3 .

Projekt $z$ dnia 31 lipca $2008 r$ ustawy o państwowym nadzorze nad systemem powszechnego ubezpieczenia zdrowotnego. Pozyskano z: http://www. mz.gov.pl/wwwfiles/ma_struktura/docs/pu_opuz_ 31072008.pdf.

Pudełkiewicz, E. (2004). Problem pomiaru (efektywności i skuteczności) w badaniach marketingowych. Prace Naukowe, 28, Katedra Polityki Agrarnej i Marketingu, Szkoła Główna Gospodarstwa Wiejskiego.

Regulowana konkurencja dla NFZ. Rozmowa z dr. B. Więckowską (2012). Stużba Zdrowia, luty.

Rekomendacje Konferencji „Biatego Szczytu” $z$ dnia 19 marca 2008 r. Pozyskano z: http://www.mz.gov. $\mathrm{pl} / \mathrm{wwwmz} / \mathrm{slajd} ? \mathrm{mr}=\mathrm{m} 0 \& \mathrm{~ms}=\& \mathrm{ml}=\mathrm{pl} \& \mathrm{mi}-$ $=\& m x=0 \& m t=\& m y=26 \& m a=010276$.

Rój, J. i Sobiech, J. (2006). Zarządzanie finansami szpitala. Warszawa: Wolters Kluwer Polska.

Różański, J. (2007). Dylematy związane z interpretacja pojęcia efektywności a obecne uwarunkowania działania przedsiębiorstwa. w: Dudycz, T., Tomaszewicz, Ł. (red.), Efektywność - rozważania nad 
istotą i pomiarem. Prace Naukowe, 1183. Wrocław: Akademia Ekonomiczna we Wrocławiu.

Rudawska, I. (2003). Imperatyw konkurencji na rynku usług medycznych. w: Piech, K. i Kulikowski, M. (red.), Przedsiębiorczość: szansa na sukces rządu, gospodarki, przedsiębiorstw, spoleczeństwa. Warszawa: Instytut Wiedzy.

Rudawska, I. (2007). Opieka zdrowotna. Aspekty rynkowe i marketingowe. Warszawa: WN PWN.

Rudawska, I. (2011). Zintegrowana opieka zdrowotna - w poszukiwaniu poprawy efektywności. Problemy Zarządzania, 3.

Rynek $w$ ochronie zdrowia? Tak, ale myślmy, co robimy. Pozyskano z: http://www.rynekzdrowia.pl/ Polityka-zdrowotna/Rynek-w-ochronie-zdrowiaTak-ale-myslmy-co-robimy,110651,14.html.

Sienkiewicz, T. (2011). NFZ - wszechpotężny kontroler. Stużba Zdrowia, 12 marca 2011.

Skrzypek, E. (2000). Jakość i efektywność. Lublin: Uniwersytet Marii Curie-Skłodowskiej.

Sochacka-Krysiak, H. (2009). Niektóre problemy efektywności w gospodarce finansowej samorządu terytorialnego. w: Wieteska, S., Wypych, M. (red.), $W$ poszukiwaniu efektywności finansów publicznych. Łodź: Uniwersytet Łódzki.

Sondaż „Zdaniem BCC” Jak przedsiębiorcy oceniaja zmiany w systemie ubezpieczeń zdrowotnych? (2011). Warszawa: Business Centre Club.

Sprawozdanie petnomocnika rzadu ds. wprowadzenia powszechnego ubezpieczenia zdrowotnego - podsumowanie. Dokument przyjęty przez rząd 20 czerwca
2000 r. Pozyskano z: http://www.poprzedniastrona. premier.gov.pl/archiwum/7810_8006.htm.

Strategia „Sprawne Państwo 2011-2020”. Projekt przeznaczony do konsultacji. Ministerstwo Spraw Wewnętrznych i Administracji, Warszawa, kwiecień 2011.

Świder, P. (2004). Skuteczność a system - finansowania ochrony zdrowia w krajach Unii Europejskiej - porównanie. Problemy Zarządzania, 4.

Szewczuk, K. (2005). Medycyna i finanse. Czy ekonomiczne racjonowanie świadczeń zdrowotnych jest sprawiedliwe? Diametros, 5: 95-96.

Szparkowska, S., Platforma już nie chce dzielić NFZ. Pozyskano z: http://www.rp.pl/artykul/257853.htm1 ? print $=$ tak $\& p=0$.

Uniknąć chaosu. Rozmowa z Jackiem Paszkiewiczem, Prezesem Narodowego Funduszu Zdrowia (2008). Menedżer Zdrowia, 1.

Watoła, J., Biurokracja NFZ wykańcza chorych. Pozyskano z: http://wiadomosci.gazeta.pl/wiadomosci/1,114873,3987801.html.

Więckowska, B. (2010). Konkurencja między ptatnikami $w$ bazowym systemie zabezpieczenia zdrowotnego. Program Sprawne Państwo. Warszawa: Ernst \& Young.

Włodarczyk, C., Proces reformowania systemów opieki zdrowotnej. Analiza doświadczeń. Pozyskano z: http://www.qcm2.quicksilver.pl/img/27/ Cezary\%20Wlodarczyk.pdf.

Wojteczek, J. (2008). Dlaczego NIE. Podział Narodowego Funduszu Zdrowia. Menedzer Zdrowia, 7. 